\title{
FOSTERING FINANCIAL INCLUSION: THE DETERMINANTS OF THE USERS BEHAVIOUR OF THE SMART ACT BRANCHLESS BANKING SERVICE
}

\author{
Supramono Supramono*, Elsa Stefanie, Theresia Woro Damayanti * \\ Universitas Kristen Satya Wacana, Salatiga, Indonesia \\ supramono@uksw.edu \\ elsastefanie1@gmail.com \\ theresia.damayanti@uksw.edu
}

\begin{abstract}
The presence of Smart Act Branchless Banking Service (SABBS) in Indonesia is expected to be able to encourage people to have bank accounts and obtain banking services so that it can increase financial inclusion. The purpose of this study is to examine the determinants of the SABBS users' behaviour based on Theory of Interpersonal Behaviour (TIB) and Technology Acceptance Model (TAM). Based on the integration of the two theories, 9 hypotheses can be formulated to be empirically tested. Based on the integration of the two theories, 9 hypotheses can be formulated. A sample of 200 respondents were obtained through a survey on the SABBS users and the data was analysed using Smart$P L S$. The results show that: (1) perceived ease of use and perceived usefulness influence attitude towards SABBS; (2) attitude, social and affective factors have an influence on intention to use SABBS; (3) intention and habits influence the SABBS users' behaviour. This study suggests that financial service authorities and the banking sector to increase financial inclusion must continue to foster public intentions to be willing to use SABBS. This can be done among others through structured and massive socialization about usefulness, easiness and security when using SABBS. This study also contributes, to reduce the research gap on the determinants of financial inclusion based on a behavioural approach.
\end{abstract}

Keywords: Financial inclusion, banking service, attitude, Intention, user behaviour

JEL classification: G32, G21, G51

\section{Introduction}

A condition of the community that has not been reached by banking industry, or commonly called the unbanked group, has a large portion in developing countries including Indonesia. In 2014, it reached $64 \%$ of Indonesia's total population of 250 million people and in 2017, along with the development of Fintech services, it dropped dramatically to 37\% (Warta Ekonomi, 2019). However, this still shows the existence of problems with financial inclusion. Financial inclusion is a process that ensures the ease of access, availability, and use of financial services for all members of the community (Sarma and Pais, 2011; Cámara and Tuesta, 2018). The existence of financial inclusion allows poor people to obtain cheaper financing (Karpowicz, 2014), increase access to financial services and reduce income inequality (Park and Mercado, 2018; Cooney and Shanks (2010). Constraints of financial inclusion can be caused by the demand side, including financial inability, financial literacy, high costs, other family members who already have a bank account, incomplete documents, disbelief, and religious reasons such as usury for bank interest (Kunt and Klapper, 2012), while in terms of supply or financial institutions, the constraints include regulatory aspects, geographical barriers, infrastructure, and connectivity.

${ }^{*}$ Corresponding author: Supramono Supramono 
In facing the challenges of financial inclusion, the Indonesian government did not only encourage the development of the fin-tech industry but also issued SABBS policy in 2015. SABBS is a collaboration of banking or other financial services with other parties (bank agents) supported by the use of information technology facilities. This service aims to eliminate all forms of public access barriers in utilizing financial services by providing simple and easily accessible financial products that are easy to understand and could meet the needs of the community. The SABBS enables the users to open a savings account through an intermediary of a bank agent instead of coming to the bank office. A similar service was also launched by Bank Indonesia under the name of digital financial services in 2013.

To encourage the use of SABBS as a financial inclusion policy instrument, it is necessary to understand factors influencing the users' behaviour of using SABBS. Several previous studies have found the determinants of financial inclusion. It was found that age, education, financial literacy, income, and internet connectivity support had a positive effect on financial inclusion (Abel et al., 2018; Zins and Weill, 2016). While others found the determinants on the supply side, such as interest rate and bank innovation (Oyelami et al., 2017), and expansion of bank branch networks (Kumar, 2013). Although there have been many studies on the determinants of financial inclusion, however, there has been no analysis based on behavioural approaches regarding the adoption of technology. The use of a behavioural approach is expected to find ways to encourage people to utilize the instruments of financial inclusion.

There are many behavioural theories that can be used to explain behavioural determinants of technology adoption or the application of a new system such as SABBS. One of them is the Theory of Interpersonal Behaviour (TIB). According to TIB, user behaviour is basically influenced by interests and habits. Furthermore, interest is influenced by attitudes, social and affective factors of service users. While attitude factors can be explored through the Theory of Technology Acceptance Model (TAM) influenced by perceived usefulness and perceived ease of use.

\section{Literature and Hypotheses Development}

\subsection{Antecedents of Attitude}

TAM, introduced by Davis (1989), is a development of Theory of Reasoned Action (Fishbein and Ajzen, 1975) which explains that one's intentions are influenced by individual attitudes and social norms. Further, in the context of the behaviour of using computer technology, TAM adds perceived ease of use (PEOU) and perceived usefulness (PU) as factors forming individual attitudes.

A person's attitude is defined as a positive or negative feeling experienced if they have to do a certain behaviour (Davis et al., 1989). Someone who considers technology to be easy to use, he/she will show a more positive attitude towards the use of technology (Juniwati, 2014). In the context of SABBS, if someone views that SABBS is a service that is easy to understand and operate, it will encourage him/her to have a positive attitude towards the SABBS. Several previous studies have found empirical evidence on positive relations between PEOU and attitude (Chawla and Joshi, 2017; Weng et al., 2018).

In addition to being influenced by PEOU, attitudes are also influenced by PU, which is defined as a level of one's belief that the use of a special system will improve the performance of their work (Davis et al., 1989). Meanwhile, Rauniar et al. (2014) mentioned $\mathrm{PU}$ as a benefit of the technological attributes used. The benefits of a system will encourage individuals to have a positive attitude (Ferguson, 1997). Conversely, if a system, such as SABBS, does not have benefits, it will produce a negative attitude towards the use of the 
system. This argument has received support from the results of previous studies (Elkaseh et al., 2016). Thus, in relation to the SABBS, the hypotheses proposed are as follows:

H1: PEOU has a positive influence on attitudes towards using SABBS

H2: PU has a positive influence on attitudes towards using SABBS.

\subsection{Attitude, Intention, Habits, and Users Behaviour of SABBS}

TIB, introduced by Triandis (1977), is the development of the Theory of Reasoned Action (TRA) and Theory of Planned Behaviour (TPB) by adding affective factors in the formation of intention. TIB explains that behaviour is formed from three dimensions including intention, habit, and facilitating conditions. However, facilitating conditions only act as moderators facilitating the realization of a behaviour. The intention representing conscious control in deciding a behaviour is formed by attitude, social and affective factors. Whereas the habit representing subconscious control in deciding a behaviour is formed from repetitive behaviour carried out in the past (frequency of past behaviour). TIB has advantages over other behavioural theories because it can distinguish cognitive and affective aspects (Bamberg and Schmidt, 2003). In the context of SABBS, cognitive aspects in TIB can be seen as attitudes towards the use of SABBS and affective aspects can be interpreted as emotional responses to the use of SABBS.

Intention is a conscious plan or decision taken by an individual to show a behaviour (Sommer, 2011). Individual attitudes are the best predictors for intention variables (Chipeta and Surujlal, 2017). Someone with a positive attitude towards SABBS has a great potential intention to use SABBS. The results of previous studies (Chawla and Joshi, 2017; Chen, 2013) also show that attitude had a significant positive effect on the intention to use banking services.

The intention to use SABBS is also influenced by social factors. Triandis (1980) defined social factors as interpersonal agreements from an individual to the community he/she adheres to in a particular social environment. Social factors represent normative beliefs of an individual (Karaiskos et al., 2012). Researches on social influences associated with behavioural intentions in the banking industry had been carried out by researches such as Abrahão et al. (2016) and Kazi and Mannan (2013) who found that social factors had a positive effect on the intention to behave.

TIB explains that affective factor, which is an emotional response directly to a thought about a particular behaviour, becomes one of the important factors forming intention (Triandis, 1980). This is because an individual can make decisions based on feelings. It represents an individual's emotional response to thoughts of doing the behaviour (Karaiskos et al., 2012). A relatively similar definition is also stated by Moody and Siponen (2013) that it is an emotional response to certain situations based on instinct and subconscious processes in the mind. Previous studies show empirical evidence that affective factor had a significant influence on the intention of using the internet (Karaiskos et al., 2012; Kabadayı and Alan, 2012).

The SABBS users' behaviour is also influenced by habits which are the subconscious control in deciding a behaviour. Repeated behaviour carried out by someone in the past, even though it is not realized, will shape the habits of an individual (Bamberg and Schmidt, 2003). Meanwhile, Moody and Siponen (2013) emphasized regularly repeated behaviours could become automatic or habitual.

Based on the TIB theory which mentions that behaviour is determined by intention, habits and facilitating condition, in the context of this study, user behaviour is measured by the actual use of SABBS to obtain financial services. Previous studies show a significant relationship between intention and behaviour (Rauniar et al., 2014). Meanwhile, habits which are psychological tendencies to repeat past behaviour (Neal et al., 2012) also influence 
behaviour. It is supported by studies on internet use (Moody and Siponen, 2013; Sharif and Raza, 2017) and car use (Setiawan et al., 2015).

TIB states that the effect of intention to use behaviour also depends on facilitating conditions, which are the assessment of each individual towards objective factors in an environment that can facilitate or complicate the occurrence of a behaviour (Triandis, 1980). It is possible that if a person has a high intention to do a certain behaviour, it will definitely fail if the infrastructure does not support the behaviour. Facilitating conditions in TIB have similar properties to perceived behavioural control in TPB. Ghalandari (2012) specifically stated that facilitating conditions refer to the extent to which one feels that the existing infrastructure supports the use of the system. Thus, it can be assumed that if the available infrastructure to use SABBS is more adequate, the influence of the intention to use SABBS on the actual use of SABBS will be greater. However, previous researches on the role of facilitating condition moderating the effect of intentions on behaviour were very limited. Most studies place facilitating conditions as factors that influence intention (Ayoade, 2015; Palau-Saumell et al., 2019). Based on the arguments above, some hypotheses can be formulated as follows:

H3: Attitudes have a positive influence on the intention to use SABBS.

H4: Social factors have a positive influence on the intention to use SABBS

H5: Affective factors have a positive influence on the intention to use SABBS.

H6: Repeated behaviour has a positive influence on habits.

H7: Intention has a positive influence on the SABBS user's behaviour.

H8: Facilitating conditions strengthen the positive influence of intention on the SABBS users' behaviour.

H9: Habit has a positive influence on the SABBS users' behaviour.

\section{Methodology}

Data obtained through field surveys by distributing questionnaires. The questions asked in the questionnaire are divided into two parts. The first part deals with demographic identity. The second part contains research instruments related to measurement of variables: SABBS, PEOU, PU, attitudes, intention, social factor, affective factor, repeated behaviour, intention, facilitating conditions and habit. SABBS is measured using 3 items. Then, PEOU, PU and attitudes each measured by 4 items were adopted from Davis et al. (1989). Intention is measured by 3 items adopted from the research of Shrestha et al. (2012). Meanwhile, social factor, affective factor and Habit each measured using 4 items adopted from Triandis (1980). Furthermore, the variable repeated behaviour consists of 4 items adopted from Bamberg and Schmidt (2003) and facilitating conditions involving 3 items adopted from Ghalandari (2012). The items above were measured using a Likert scale consisting of a 5point ratings of agreement ( 1 - strongly disagree, 5 - strongly agree).

The target sample was the SABBS users in Kudus Regency, Indonesia - a pioneer area for SABBS. During a three-month field survey, 200 respondents were obtained. Meanwhile, the total measurement item is 37 , according to the suggestion by Hair et al. (2006) that the minimum number of samples is 5 times the number of measurement items, at least 185 respondents are needed so that the sample size obtained is relatively adequate for analysis purposes. The profile of the respondents shows that most of them were over 40 years old $(31 \%)$ and most of them are men (53\%), worked as entrepreneurs, and had a high school level of education (60\%).

Testing of the instrument quality involved validity and reliability tests. The results of the validity test show that all measurement items have AVE values of $>0.5$ and the loading factor of $>0.7$. The reliability test using Cronbach's alpha and Composite Reliability is all $>$ 0.7. Therefore, the research instrument used was valid and reliable. Furthermore, due to the 
consideration of data distribution patterns, Smart-PLS was employed to conduct data analysis.

\section{Results}

The users' behaviour, facilitating conditions, intention, habits, attitudes, social factors, affective factors, repetitive behaviour, perceived usefulness, and perceived of ease of use variables have an average mean ranging from $4.00-4.44$ with a standard deviation of 0.53 -0.78 .

Table 1: Descriptive Statistics

\begin{tabular}{|l|c|c|c|c|}
\hline \multicolumn{1}{|c|}{ Variable } & Min & Max & Mean & Std. Dev \\
\hline PEOU & 3 & 5 & 4.40 & 0.56 \\
\hline PE & 3 & 5 & 4.43 & 0.55 \\
\hline Attitudes & 3 & 5 & 4.25 & 0.53 \\
\hline Social factors & 3 & 5 & 4.00 & 0.78 \\
\hline Affective factors & 3 & 5 & 4.42 & 0.57 \\
\hline Repetitive behaviour & 2 & 5 & 4.17 & 0.54 \\
\hline Intention & 3 & 5 & 4.44 & 0.55 \\
\hline Habits & 3 & 5 & 4.19 & 0.58 \\
\hline Facilitating conditions & 3 & 5 & 4.44 & 0.55 \\
\hline Users' behaviour & 3 & 5 & 4.41 & 0.57 \\
\hline
\end{tabular}

To determine the ability of endogenous variables to explain the diversity of exogenous variables, Goodness of Fit (GoF) test was done. GoF is tested using R-square dependent latent variables with the same interpretation as regression. While Q-Square is a predictive relevance for a structural model that measures how well the observation value is generated by the model and also its parameter estimation. The results of the Goodness of fit model are summarized in Table 2 below

Tables 2: Goodness of Fit

\begin{tabular}{|l|c|}
\hline Variables & R-Square \\
\hline Attitudes & 0.471 \\
\hline Intention & 0.353 \\
\hline Habits & 0.673 \\
\hline Users' Behaviour & 0.744 \\
\hline Q-Square & 0.834 \\
\hline GoF & 0.680 \\
\hline
\end{tabular}

The value of the R-square shown in Table 2, which is the contribution of each exogenous variable to endogenous variables, ranges from $36.5 \%$ to $74.4 \%$. The overall Q-square value of the construct is $83.4 \%$. This indicates that the diversity of behavioural variables of using SABBS could be explained by the overall model of $83.4 \%$. The result of Goodness of Fit (GoF) value is considered in the high category (0.680). Therefore, the model is fit for the purpose of testing the hypothesis (Figure 1). 


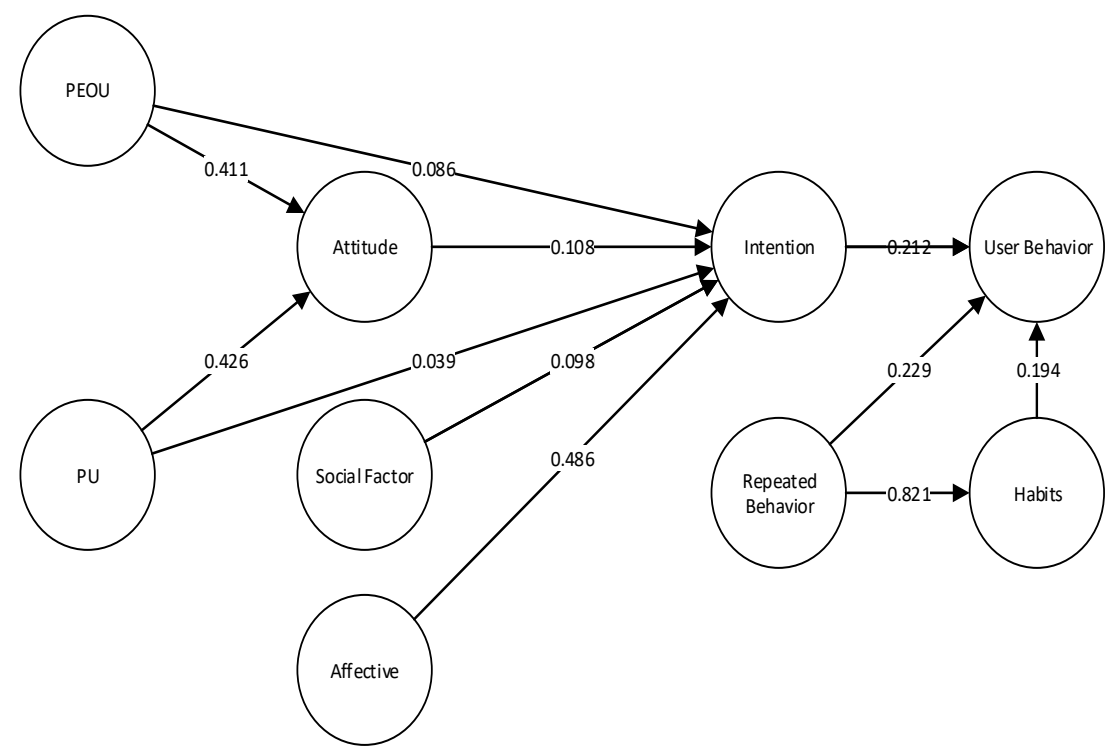

Figure 1: The Research Model

The results of partial testing of each hypothesis are presented in Table 3. PEOU and PU have a positive and significant effect on attitude $(\beta=0.411, p<0.01 ;(\beta=0.426, p<0.01)$, resulting to $\mathrm{H} 1$ and $\mathrm{H} 2$ to be accepted. Attitude, social and affective factors have a positive and significant influence on intention $(\beta=0.108, p<0.1 ; \beta=0.259, p<0.01 ; \beta=0.486, p<$ 0.010 ), making $\mathrm{H} 3, \mathrm{H} 4$ and $\mathrm{H} 5$ to be supported. Repeated behaviour has a significant effect on habits $(\beta=0.821, p<0.01)$ so that $\mathrm{H} 6$ is also supported. Then, intention and habits significantly influence the SABBS user' behaviour $(\beta=0.212, p<0.01 ;(\beta=0.194, p<0.01)$. Thus, $\mathrm{H} 7$ and $\mathrm{H} 9$ are accepted. The only rejected hypothesis is $\mathrm{H} 8(=0.031, p>0.1)$, which means that the facilitating conditions do not strengthen the influence of intentions on the behaviour of using SABBS

Table 3: Hypothesis Testing

\begin{tabular}{|c|l|c|c|c|}
\hline Hypothesis & $\begin{array}{c}\text { Original } \\
\text { Sample (0) }\end{array}$ & P-Values & Result \\
\hline H1 & PEOU -> Attitude & 0.411 & 0.000 & Accepted \\
\hline H2 & PE -> Attitude & 0.426 & 0.000 & Accepted \\
\hline H3 & Attitude -> Intention & 0.108 & 0.058 & Accepted \\
\hline H4 & Social Factor -> Intention & 0.259 & 0.000 & Accepted \\
\hline H5 & Affective Factor - Intention & 0.486 & 0.000 & Accepted \\
\hline H6 & $\begin{array}{l}\text { Repeated Behaviour -> } \\
\text { Habits }\end{array}$ & 0.821 & 0.000 & Accepted \\
\hline H7 & Intention -> Users' Behaviour & 0.212 & 0.000 & Accepted \\
\hline H8 & $\begin{array}{l}\text { Interaction (Facilitating } \\
\text { Condition \& Intention)-> } \\
\text { Users' Behaviour }\end{array}$ & 0.031 & 0.369 & Rejected \\
\hline H9 & Habits -> Users' Behaviour & 0.194 & 0.000 & Accepted \\
\hline
\end{tabular}


Besides testing hypotheses for direct effects between variables, it was also interesting to analyse indirect effects, so that it could be seen whether certain variables such as attitudes, intentions, and habits were able to mediate certain variables used. Variance Accounted For (VAF) method is the result of the division of the indirect effect with the total effect and it can be grouped into the following categories: (1) it is a full mediator if the VAF value is $>80 \%$; (2) it is a partial mediator if the VAF is between $20 \%-80 \%$; and (3) it is not a mediator if the VAF is $<20 \%$ (Hair et al., 2013). Table 3 shows that attitude is a partial mediator of the influence of PEOU and PE on intention. Whereas, intention can be categorized as a partial mediator in mediating the influence of attitudes and social factors on users' behaviour. Intention has a role as a full mediator in mediating the influence of affective factors on users' behaviour. Then, the habit that mediates the influence of past repetitive behaviour on user behaviour is also considered as a partial mediator.

Table 4: Results of Direct and Indirect Effects and VAF

\begin{tabular}{|c|c|c|c|c|}
\hline Direct Effect & Indirect Effect & $\begin{array}{l}\text { Total } \\
\text { Effect }\end{array}$ & VAF & Result \\
\hline $\begin{array}{l}\text { PEOU --> Intention } \\
(0.086)\end{array}$ & $\begin{array}{l}\text { PEOU -->Attitude * Attitude --> } \\
\text { Intention } \\
\left(0.411^{*} 108=0.044\right)\end{array}$ & 0.130 & 0.338 & $\begin{array}{l}\text { Partial } \\
\text { Mediator }\end{array}$ \\
\hline $\begin{array}{l}\text { PE --> Intention } \\
(0.076)\end{array}$ & $\begin{array}{l}\text { PE -->Attitude * Attitude -- } \\
\text { >Intention } \\
(0.4260 .108=0.046)\end{array}$ & 0.122 & 0.377 & $\begin{array}{l}\text { Partial } \\
\text { Mediator }\end{array}$ \\
\hline $\begin{array}{l}\text { Attitude --> Users' } \\
\text { Behaviour }(0.039)\end{array}$ & $\begin{array}{l}\text { Attitude -> Intention * Intention } \\
-->\text { Users' Behaviour } \\
\left(0.212^{*} 0.108=0.023\right)\end{array}$ & 0.062 & 0.371 & $\begin{array}{l}\text { Partial } \\
\text { Mediator }\end{array}$ \\
\hline $\begin{array}{l}\text { Social Factor -- } \\
\text { > Users' Behaviour } \\
(0.098)\end{array}$ & $\begin{array}{l}\text { Social Factor --> Intention * } \\
\text { Intention }-->\text { Users' Behaviour } \\
\left(0.259^{*} 0.212=0.055\right)\end{array}$ & 0.153 & 0.359 & $\begin{array}{l}\text { Partial } \\
\text { Mediator }\end{array}$ \\
\hline $\begin{array}{l}\text { Affective Factor --> } \\
\text { Users' Behaviour } \\
(0.024)\end{array}$ & $\begin{array}{l}\text { Affective Factor }-->\text { Intention * } \\
\text { Intention }-->\text { Users' Behaviour } \\
\left(0.486^{*} 0.212=0.103\right)\end{array}$ & 0.127 & 0.811 & $\begin{array}{l}\text { Full } \\
\text { Mediator }\end{array}$ \\
\hline $\begin{array}{l}\text { Repeated } \\
\text { Behaviour --> } \\
\text { Users' Behaviour } \\
(0.229)\end{array}$ & $\begin{array}{l}\text { Repeated Behaviour --> Habits } \\
{ }^{*} \text { Habits --> Users' Behaviour } \\
\left(0.821^{*} 0.194=0.159\right)\end{array}$ & 0.388 & 0.410 & $\begin{array}{l}\text { Partial } \\
\text { Mediator }\end{array}$ \\
\hline
\end{tabular}

\section{Discussion}

The objective of this study was to examine the determinants of the SABBS users' behaviour by proposing nine hypotheses. The results show that almost all hypotheses are confirmed, except for one hypothesis which states that facilitating conditions strengthen the positive influence of intention on the SABBS users' behaviour. POEU and PU have a significant positive effect on attitudes. This means that if the users did not experience any difficulties in using SABBS, they would show a positive attitude towards the SABBS. Similarly, if they experienced many benefits of using SABBS, they would also show a positive attitude towards the SABBS. These results support previous researches which found that a person's attitude was highly influenced by their perceived ease of use (Chawla and Joshi, 2017; Weng et al., 2018) and perceived usefulness (Elkaseh et al., 2016).

The attitude towards the use of SABBS which has a significant positive effect on intention can be interpreted that if SABBS was able to form a positive attitude, then it could create the intention to use the SABBS. This result is in accordance with studies conducted by Chen 
(2013). Furthermore, the positive attitude of the user had an important role to support the success of SABBS in an effort to improve financial inclusion. The results of the study also show that attitudes were also able to mediate the influence of perceived ease of use and perceived usefulness on intention.

Besides being influenced by attitude, intention is also influenced by social and affective factors. Social factors, in this case, refer to the encouragement of people in the surrounding environment and affective factors in the form of feeling comfortable in using SABBS can encourage one's intention to use SABBS. This finding corroborates the results of research on the positive influence of social factors (Abrahão et al., 2016; Kazi and Mannan, 2013) and affective factors (Karaiskos et al., 2012) on intention. Furthermore, the results of this study prove that intention is a determinant of the SABBS users' behaviour. The greater the intention of an individual towards the SABBS, the higher the tendency for someone to use the SABBS for daily financial transactions.

Repeated behaviours carried out by users in the past are proven to form the users' habits in using the SABBS as a means of non-cash transactions. This result is in line with Bamberg and Schmidt (2003) who claimed that behaviour carried out repeatedly would form habits and eventually, it would be automatic (Moody and Siponen, 2013).

The results also reveal that the facilitating conditions including a number of SABBS agents, the proximity of the location of SABBS agents to the user's residence, and affordability of costs were not able to strengthen the influence of intentions on the behaviour of using SABBS. This result is likely due to the limited number of agents. In addition, the cost of noncash transactions in agents was perceived to be expensive

\section{Conclusion and Policy Implication}

The analysis of the determinants of the SABBS users' behaviour shows that the perceived ease of use and perceived usefulness influence the users' attitudes. Then, the attitudes along with social and affective factors influence the intention to use SABBS. Other results also reveal that the repetitive behaviours carried out in the past affect habits. Finally, the intention and habit would determine whether the user would consider SABSS as a non-cash transaction medium, where the user did not need to go to the bank but it could be done through agents appointed.

The results of this study are able to prove that the integration of the Technology Acceptance Model (TAM) and Theory of Interpersonal Behaviour (TIB) model was able to explain more comprehensively about one's behaviour towards the adoption of innovations in the form of the use of SABBS to improve financial inclusion. This study encourages financial inclusion and shows that there is a need for the financial services authority and the banking sector to continuously grow the public's intention to use the SABBS. This can be done through structured and massive socialization of the benefits and easiness of using SABBS. Besides, it is also important to emphasize the use of SABBS as a means of safe transactions.

There were several limitations in terms of samples where this study only took samples from respondents who had used SABBS which might lead to biased conclusions about the influence of intentions on behaviour to use SABBS. However, still, there will be a possibility that if the respondents have not used SABBS, they may have high intentions of using SABBS, but does not necessarily use it. Therefore, the intention would not always influence behaviour. Future researches are suggested to expand the scope of the sample, not only from users but also respondents who have not used SABBS 


\section{References}

Abel, S., Mutandwa, L. and Roux, P. L. 2018. A Review of Determinants of Financial Inclusion. International Journal of Economics and Financial Issues, 8(3), pp. 1-8.

Abrahão, R. de S., Moriguchi, S. N. and Andrade, D. F. 2016. Intention of adoption of mobile payment: An analysis in the light of the Unified Theory of Acceptance and Use of Technology (UTAUT). Revista de Administração e Inovação, 13, pp. 221-230. https://doi.org/10.1016/i.rai.2016.06.003

Ayoade, B. O. 2015. Factors influencing students' behavioural intention to adopt and use mobile learning in higher educational institutions in Nigeria: An example of Ekiti State University, Ado-Ekiti. International Journal of Emerging Technology and Advanced Engineering, 5(4), pp. 307-313.

Bamberg, S. and Schmidt, P. 2003. Incentives, morality, or habit? Predicting students' car use for university routes with the models of Ajzen, Schwartz, and Triandis. Environment \& Behaviour, 35, pp. 264-285. https://doi.org/10.1177/0013916502250134

Cámara, N. and Tuesta, D. 2018. Measuring financial inclusion: a multidimensional index, IFC Bulletin Chaptes in: Bank for International Settlements.

Chipeta, E.M. and Surujlal, J. 2017. Influence of attitude, risk-taking propensity and proactive personality on social entrepreneurship intentions. Polish Journal of Management Studies, 15(2), pp. 27-36. https://doi.org/10.17512/pjms.2017.15.2.03

Chawla, D. and Joshi, H. 2017. High versus low consumer attitude and intention towards adoption of mobile banking in India: An empirical study. Vision: The Journal of Business Perspective, 21(4), pp. 1-15. https://doi.org/10.1177/0972262917733188

Chen, C. 2013. Perceived risk, usage frequency of mobile banking services. Managing Service Quality: An International Journal, 23(5), pp. 410-436. https://doi.org/10.1108/MSQ10-2012-0137

Cooney, K. and Shanks, T. R. W. 2010. New approaches to old problems: market-based strategies for poverty alleviation. Social Service Review, 84, pp. 29-55. https://doi.org/10.1086/652680

Davis, F. D. 1989. Perceived usefulness, perceived ease of use, and user acceptance of information technology. MIS Quarterly, 13(3), pp. 319-340. https://doi.org/10.2307/249008

Davis, F. D., Bagozzi, R.P and Warshaw, P.R. 1989. User acceptance of information technology: A comparison of two theoretical Model. Management Science, 35(8), pp. 9821003. https://doi.org/10.1287/mnsc.35.8.982

Elkaseh, A. M., Wong, K. W. and Fung, C. C. 2016. Perceived ease of use and perceived usefulness of social media for e-learning in Libyan higher education: A structural equation modelling analysis. International Journal of Information and Education Technology, 6(3), pp.192-199. http://dx.doi.org/10.7763/IJIET.2016.V6.683

Ferguson, C.1997. The effect of microcomputers on the work of professional accountants. Accounting and Finance, 37, pp. 41-67. https://doi.org/10.1111/j.1467-629X.1997.tb00313.x Fishbein, M. and Ajzen, I. 1975. Belief, Attitude, Intention and Behavior: An Introduction to Theory and Research, Addision-Wesley

Ghalandari, K. 2012. The effect of performance expectancy, effort expectancy, social influence and facilitating conditions on acceptance of e-banking services in Iran: The moderating role of age and gender. Middle East Journal of Scientific Research, 12 (6), pp. 801-80. https://doi.org/10.5829/idosi.mejsr.2012.12.6.2536

Hair, J.F, Black, W.C., Babin, B.J. and Anderson, R.E. 2006. Multivariate data analysis, 6th ed. New Jersey: Pearson Education.

Juniwati. 2014. Influence of perceived usefulness, ease of use, risk on attitude and intention to shop online. European Journal of Business and Management, 6(27), pp. 218-229. 
Kabadayı, E. T. and Alan, A. K. 2012. Revisit intention of consumer electronics retailers: Effects of customers' emotion, technology orientation and WOM influence. Procedia - Social and Behavioral Sciences, 41, pp. 65-73. https://doi.org/10.1016/j.sbspro.2012.04.009

Karaiskos, D.C., Drossos, D.A., Tsiaousis, A.S., Giaglis, G.M. and Fouskas, K.G. 2012. Affective and social determinants of mobile data service adoption. Behaviour \& Information Technology, 31, pp. 209-219. https://doi.org/10.1080/0144929X.2011.563792

Karpowicz, I. 2014. Financial inclusion, growth and inequality: A model application to Colombia. IMF Working Paper.

Kazi, A. K. and Mannan, M. A, 2013. Factors affecting adoption of mobile banking in Pakistan: Empirical Evidence. International Journal of Research in Business and Social Science, 2(3), pp. 54-61. https://doi.org/10.20525/ijrbs.v2i3.73

Kumar, N. 2013. Financial inclusion and its determinants: Evidence from India. Journal of Financial Economic Policy, 5(1), pp. 4-19. https://doi.org/10.1108/17576381311317754

Kunt, A. D. and Klapper, L. 2012. Measuring financial inclusion: The global findex. Policy Working Paper. The World Bank Development Research Group Finance and Private Sector Development Team.

Oyelami, L, O., Saibu, O. M. and Adekunle, B. 2017. Determinants of financial inclusion in Sub-Sahara African Countries. CJBSS, 8(2), pp. 104-116.

Moody, G.D. and Siponen, M. 2013. Using the theory of interpersonal behaviour to explain non-work-related personal use of the internet at work. Information \& Management, 50, pp. 322-335. https://psycnet.apa.org/doi/10.1016/j.im.2013.04.005

Neal, D. T., Wood, W., Labrecque, J. S. and Lally, P. 2012. How do habits guide behaviour? Perceived and actual triggers of habits in daily life. Journal of Experimental Social Psychology, 48(2), pp.492-498. http://dx.doi.org/10.1016/i.jesp.2011.10.011

Palau-Saumell, R., Forgas-coll, S., Javier, S. and Robres, E. 2019. User acceptance of mobile apps for restaurants: An expanded and extended UTAUT-2. Sustainability, 11(4), pp. 1-24. https://doi.org/10.3390/su11041210

Park, C.Y. and Mercado, R. V. 2018. Financial inclusion: New measurement and crosscountry impact assessment, ADB Economics Working Paper Series, 539. http://dx.doi.org/10.22617/WPS189270-2

Rauniar, R., Rawski, G., Yang, J. and Johnson, B. 2014. Technology acceptance model (TAM) and social media usage: An empirical study on Facebook. Journal of Enterprise Information Management, 27(1), pp. 6-30. http://dx.doi.org/10.1108/JEIM-04-2012-0011

Sarma, M. and Pais, J.2011. Financial inclusion and development. Journal of International Development, 628, pp. 613-628. https://doi.org/10.1002/jid.1698

Sharif, A., and Raza, S. A. 2017. The influence of hedonic motivation, self-efficacy, trust and habit on adoption of internet banking: A case of developing country. International Journal of Electronic Customer Relationship Management, 11(1), pp.1-22. https://doi.org/10.1504/IJECRM.2017.086750

Setiawan, R., Santosa, W. and Sjafruddin, A. 2015. Effect of habit and car access on student behavior using cars for traveling to campus. Procedia Engineering, 125, pp. 571-578. https://doi.org/10.1016/i.proeng.2015.11.063

Shrestha, S.K., Burns, R.C., Deng, J., Confer, J., Graefe, A.R. and Covelli, E.A. 2012. The Role Elements of Theory of Planned Behaviour in Mediating the Effects of Constraints on Intentions: A Study of Oregon Big Game Hunters. Journal of Park and Recreation Administration, 30(2), pp.41-62.

Sommer, L. 2011. The Theory Of Planned Behaviour And The Impact Of Past Behaviour. International Business \& Economics Research Journal, 10(1), pp. 91-110. https://doi.org/10.19030/iber.v10i1.930

Triandis, H.C. 1977. Interpersonal behaviour, Monterey: Brooks/Cole. 
Triandis, H.C. 1980. Values, attitudes, and interpersonal behaviour. Nebraska Symposium on Motivation, 27, pp. 195-259.

Warta Ekonomi.2019. Unbanked People Bikin Bisnis Fintech Menjamur [Online access on May 24].

Weng, F., Yang, R., Ho, H. and Su, H. 2018. A TAM-based study of the attitude towards use intention of multimedia among school teachers. Applied System Innovation, 1(36), pp. 2-9. https://doi.org/10.3390/asi1030036

Zins, A. and Weill, L. 2016. The determinants of financial inclusion in Africa. Review of Development Finance, 6(1), pp. 46-57. https://doi.org/10.1016/.r.rdf.2016.05.001

\section{Bio-note}

Supramono Supramono is professor in Finance at the Department of Management of Faculty of Economics and Business, Universitas Kristen Satya Wacana, Indonesia. His research interests include Behavioural Finance, Capital Market and Corporate Finance and corporate tax. He has published several articles in reputable international journals

Elsa Stefanie is an alumnus of the Master of management program, Faculty of Economics and Business, Universitas Kristen Satya Wacana, Indonesia. Currently working at PT Sumber Kopi Prima which produces instant coffee under the Caffino brand.

Theresia Woro Damayanti is associate professor at the Department of Accounting of Faculty of Economics and Business, Universitas Kristen Satya Wacana. She is also head of the Department of Accounting. Her research interests include taxation and tax system evaluation. 